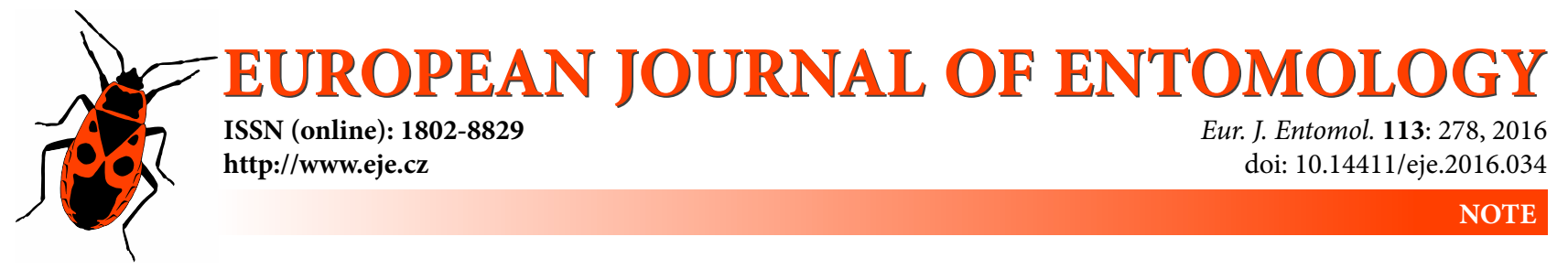

\title{
Saprinosternus nom. n., a new replacement name for Alienosternus Lackner, 2016 (Coleoptera: Histeridae), non Alienosternus Martins, 1976 (Coleoptera: Cerambycidae)
}

\author{
TOMÁš LACKNER* \\ Czech University of Life Sciences, Faculty of Forestry and Wood Sciences, Department of Forest Protection and Entomology, \\ Kamýcká 1176, 16521 Praha 6 - Suchdol, Czech Republic; e-mail: tomaslackner@me.com
}

Key words. Coleoptera, Histeridae, Saprininae, Saprinosternus, Alienosternus, nomenclature, homonym, new replacement name

\begin{abstract}
The subgenus Alienosternus Lackner, 2016 of the genus Phoxonotus Marseul, 1862 (Coleoptera: Histeridae), described in Eur. J. Entomol. 113: 240-258, is a junior homonym of Alienosternus Martins, 1976 (Coleoptera: Cerambycidae) and is hereby replaced by Saprinosternus nom. n. The status of the single known type specimens of Phoxonotus suturalis Lewis, 1907, $P$. lectus Lewis, 1902 and P. venustus (Erichson, 1834) (assumed to be holotypes in Lackner, 2016) is clarified.
\end{abstract}

ZooBank Article LSID: C8328A4B-6DA0-4EEE-9857-892A6B790C1C

Alienosternus Lackner, 2016 (described as a subgenus of Phoxonotus Marseul, 1862; Coleoptera: Histeridae) is a junior homonym of the genus Alienosternus Martins, 1976 (Coleoptera: Cerambycidae) and is hereby replaced.

Subgenus Saprinosternus nom. $\mathbf{n}$.

ZooBank taxon LSID:

317FF77A-883D-4C99-B41C-E82AD65DC134

Alienosternus Lackner, 2016: 253, non Alienosternus Martins, 1976: 230 .

Type species (by objective synonymy with and original designation for Alienosternus Lackner, 2016): Saprinus venustus Erichson, 1834.

Etymology. The name Saprinosternus refers to the sternum of this subgenus, which resembles that of the majority of Saprininae and differs from the nominotypical subgenus Phoxonotus. Gender masculine.

\section{Nomenclatoric note}

Single type specimens were found and studied by Lackner (2016) for each of the following species: Phoxonotus suturalis Lewis, 1908 (synonymized with $P$. tuberculatus Marseul, 1862 in Lackner, 2016), P. lectus Lewis, 1902 and P. venustus (Erichson, 1834). The original descriptions do not specify the number of type specimens, but do not indicate that more than one existed for each of the above species. The single specimens were thus assumed to be holotypes (see notes at the latter two species on pp. 249 and 254 in Lackner, 2016). However, the International
Code of Zoological Nomenclature recommends avoiding such holotype assumption when it is possible that the taxon was based on more than one specimen (International Commission on Zoological Nomenclature, 1999, Recommendation 73F). Therefore the single known type specimens should not have been named holotypes, would become syntypes if additional type specimens were found, and would be available for lectotype designation (if considered appropriate) even without the proof of existence of additional syntypes.

ACKNOWLEDGEMENTS. I thank A. Newton (Field Museum of Natural History, Chicago, USA) for bringing this homonymy to my attention. My wife P. Artimová is being thanked for the help with Latin and with creating the replacement name.

\section{REFERENCES}

International Comission on Zoological Nomenclature 1999: International Code of Zoological Nomenclature. 4th ed. The International Trust for Zoological Nomenclature, London, xxix $+306 \mathrm{pp}$.

LaCKNeR T. 2016: Revision of the attaphilous genus Phoxonotus (Coleoptera: Histeridae: Saprininae). — Eur. J. Entomol. 113: 240-258.

Martins U.R. 1976: Sistemática e evolução da tribo Piezocerini (Coleoptera, Cerambycidae). - Arq. Zool. 27: 165-370.

Received March 22, 2016; accepted March 22, 2016 Published online March 23, 2016

\footnotetext{
* Present address: Bavarian State Collection of Zoology, Münchhauserstraße 21, 81247 Munich, Germany. 